\title{
インバー特性を持つ $\left(\mathrm{Mn}_{1-x} \mathrm{Cr}_{x}\right) \mathrm{B}$ および $\left(\mathrm{Mn}_{1-x} \mathrm{Fe}_{x}\right) \mathrm{B}$ 系化合物
}

\author{
重 松 利彦* 金井塚唯人** 可知祐 次*
}

Toshihiko Shigematsu, Tadahito Kanaizuka and Sukeji Kachi : Invar Characteristics in $\left(\mathrm{Mn}_{1-x} \mathrm{Cr}_{x}\right) \mathrm{B}$ and $\left(\mathrm{Mn}_{1-x} \mathrm{Fe}_{x}\right) \mathrm{B}$. Thermal expansivity measurements were made on polycrystalline sintered $\left(\mathrm{Mn}_{1-x} \mathrm{Cr}_{z}\right) \mathrm{B}$ and $\left(\mathrm{Mn}_{1-x} \mathrm{Fe}_{x}\right) \mathrm{B}$. These compounds show an anomalous thermal expansivity, similar to that of the invar alloys. Near the Curie temperature MnB shows a steep descent in the thermal expansivity curve, leading to a large negative thermal expansion coefficient. With the addition of $\mathrm{Cr}$, the thermal expansion coefficient below the Curie temperature becomes smaller. The mean thermal expansion coefficient of $\left(\mathrm{Mn}_{0.88} \mathrm{Cr}_{0.12}\right)$ B from $100 \mathrm{~K}$ to $500 \mathrm{~K}$ is about $1 \times 10^{-6} \mathrm{deg}-1$. This anomaly is explained as being a result of a large spontaneous volume magnetostriction. Magnetovolume effect of these materials are discussed on the basis of the band model of ferromagnetism.

(Received March 5, 1976)

\section{I. 緒言}

從来，インバー合金は，Fe-Ni，Fe-Ptなど，面心立方 唱の鉄基合金に限られて和りここ机らの小さな熱膨張係数 は，強磁性の発生にともなら大きな正の体積磁歪と格子程 動の非调和項による正規の熱膨張とが互い打号消し合ら こと汇よりあらわれると考兄られてきた，关のため，イン バー合金の開発は，鉄基面心立方晶・強磁性合金集中乙 て行なわれてきた。

そころが，最近，インバー特性は鉄基立すj晶・強磁性合 金に固有の現象でなく，他の合金系，化合物汇も存在する ことが見出されてきた，それらとしては，深道，斎藤等に よるク口ム基体心立方品, 反強䣲性合金 ${ }^{(1) \sim(3)}$, Buschow 等(4), 志贺(5) に上る稀土類 $-3 d$ 遷移金属ラーべス相合金,

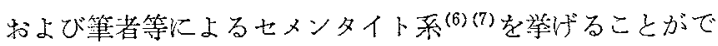
きる。これらの結果，インバー特性は，鉄基面心立坊奛合 金们限られた特徵ではなく，磁気变態点に打沙る大きな磁 気体積效果の标在によって，大小はあ机，多くの合金系， 化合物心でる見出される現象で劣るといえる。巡回電子模 型を用いて，インバー特性を磁気变態点心特汁る自発磁気 モーメントの減少火より，格子が収縮することによって説 明しようとする試みが志賀 ${ }^{(8)}$ 就よび Schlosser ${ }^{(9)}$ とより行 なわれている。インバー特性を持つ非面心立方晶合金，化 合物を新たに見つ讨出すことは新しいインバー材料の開発 という面で興味深いだけでなく，同時伅，い和ゆるインバ 一問題，なぜ，五る狭い組成筹围の合金，化合物にたけイ ンバー特性が現われるか，またその原因はなにかの解決に 関して，一つの手がかりを与交てくれることが予想され る.

$3 d$ 遷移金属䀧化物 $(\mathrm{MeB})$ は，金属原子が $\mathrm{Mn}, \mathrm{Fe}$ で は，斜方晶 $\mathrm{FeB}$ 型(B 27)，また Crでは，斜方晶 $\mathrm{CrB}$ 型
(B 33)の結晶構造を持ち，それ厹れは固溶体を作る(10). これらの化合物の磁気モーメント，キェリ一温度が，金属 原子 1 個当りの平均外殼電子数 $e / a$ で整理でき, スレー ター・ポーリング曲線的な挙動を示すことが, Cadeville 等(11)，拉よび Lundquist 等(12)によって報告されている。 磁気モーメントは，MnBで最大值 $1.9 \mu_{\mathrm{B}}$ を，キェリ一温 度は $\left(\mathrm{Mn}_{0.5} \mathrm{Fe}_{0.5}\right)$ Bで最大值 $800 \mathrm{~K}$ を持ち，e/a がその值 より增加するか，減少するに従い，それらの值は減少，降 下する。これらの磁気的性質は Lundquist 等(13)によって 提唱された 3 バンド模型に上り，ち香く説明されている。

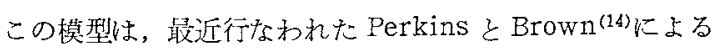
偏極中性子線回折による強磁性 $\mathrm{FeB} の$ スピン密度分有の 㵋定結果からる支持さ机ている。徍らによると， $\mathrm{FeB} て ゙ の$ フェルミ面は, +スピン $3 d$ バンドの上の端に苯り，3dバ ンドは，金属鉄の $3 d$ バンドより少し広がっている。 唧素の $2 s ， 2 p$ 結合バンドは，3dバンドと重なっている

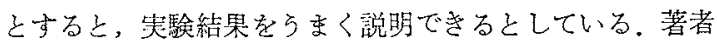
等 ${ }^{(15)}$ は, 以前, 強磁性 $\mathrm{MnB}$ 化合物の熱膨張の睍定を行な い,キュリ一温度直下で，強磁㫦の発生にともなら大きな 正の体樌磁歪に起因する，急激な格子の収縮を観測し，そ

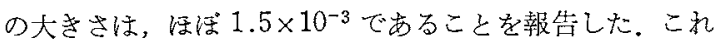
らの結果に着目して， $\left(\mathrm{Mn}_{1-x}-\mathrm{Cr}_{x}\right) \mathrm{B}$ および $\left(\mathrm{Mn}_{1-x} \mathrm{Fe}_{x}\right) \mathrm{B}$ 采化合物の熱膨張の測定を行なった。年の結果, 新しい優 れたインバー特性を持つ材料を見つけたので，報告する。

\section{II. 実 験 方 法}

化合物の材料としては，純度 $99.5 \%$ Mn，99.5\%の $\mathrm{Cr}, 99.9 \%$ の $\mathrm{Fe}$ 就よび 99\%のB走用いた。こ机らを所

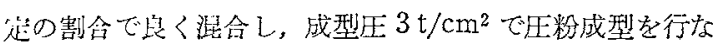
った。これを石英管中に真空封入して，1100年で $100 \mathrm{hr}$ 仮焼結を行なった。均一な試料を得るために $3 \mathrm{t} / \mathrm{cm}^{2}$ の成

* 京都大学理学部(Faculty of Science, Kyoto University, Kyoto)

**京都大学大学院 (Graduate School, Kyoto University, Kyoto) 
型圧で再圧緶，再成型し，石芙管中に真空封入し， $1150^{\circ} \mathrm{C}$ で70 hr 焼結した。このようにして得た化合物陚料から， 短册状 $(6 \times 6 \times 10 \mathrm{~mm})$ の試料を切り出し，熱膨張の測定に 供した。

各試料は，X線回折により，単暞であることを確認した。

熱膨張の測定は，差動トランスを用いた縌型の熱膨張計 を用い，77 K からキュリー温度以上までの温度範团で行 なった。

\section{III． 実験結果および考察}

$\left(\mathrm{Mn}_{1-x} \mathrm{Cr}_{x}\right) \mathrm{B}$ 系の熱膨至曲線を Fig.1亿示す。牛を 一温度は，図中に矢印で示した，X線回折の結果から，こ の系は， $x \leqq 0.6$ では，FeB 型の単相であり， $x>0.6 て ゙$ は，CrB型の単相であることを確認した。このため試料 1〜6は $\mathrm{FeB}$ 型，試料 7,8は CrB 型の結晶構造をとって

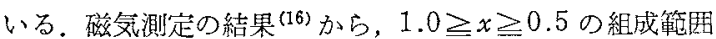
の試料は， $4 \mathrm{~K}$ でも強磁性自㢸磁気、モーメントを持たず， 帯磁率は，キュリー・ワイス則にのっている。このため， 試料 $6,7,8$ の熱膨張曲線は，常磁性状態でのものであり， 正規の熱膨張を示している。また互いに結晶構造の違う試 料 6 と試料 7,8 の爇膨張曲線とは類似している。このこ とは，CrB 之 FeB 両結晶構造の類似性加与西支持され $\zeta^{(17)}$.

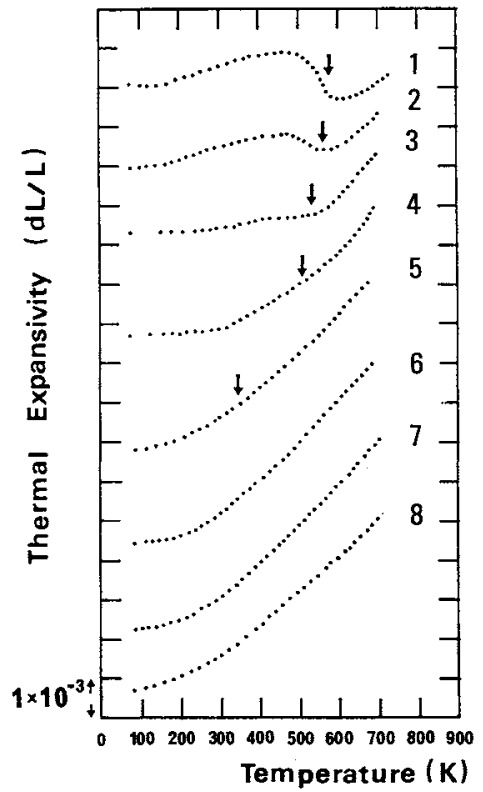

$1: \operatorname{MnB}, 2:\left(\mathrm{Mn}_{0.96} \mathrm{Cr}_{0.04}\right) \mathrm{B}, 3:\left(\mathrm{Mn}_{0.88} \mathrm{Cr}_{0.12}\right) \mathrm{B}$, $4:\left(\mathrm{Mn}_{0.80} \mathrm{Cr}_{0.20}\right) \mathrm{B}, 5:\left(\mathrm{Mn}_{0.69} \mathrm{Cr}_{0.31}\right) \mathrm{B}, 6:$ $\left(\mathrm{Mn}_{0.42} \mathrm{Cr}_{0.58}\right) \mathrm{B}, 7:\left(\mathrm{Mn}_{0.30} \mathrm{Cr}_{0.70}\right) \mathrm{B}, 8: \mathrm{CrB}$

Fig.1 Temperature dependence of the thermal expansivity of $\left(\mathrm{Mn}_{1-x} \mathrm{Cr}_{x}\right)$ B. The arrows indicate the Curie temperatures determined by magnetic measurements(16). The numbers shown in the figure indicate the sample numbers.
Fig.2に $\left(\mathrm{Mn}_{1-x} \mathrm{Fe}_{x}\right) \mathrm{B}$ 系での熱膨㗒を示す。キュリ一

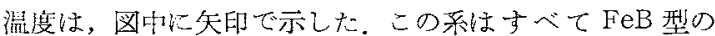
絬晶構造を持ち, 強磁性を示す。 $x \geqq 0.60$ の試料(試料 $12,13)$ では， $x<0.60$ での試料のように，キェリ一温度近 傍で，熱膨登助線に異常を示さなかった。

Fig.1 およびFig.2に示した樊膨張特性を以下の上万に 整理できる。

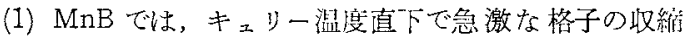

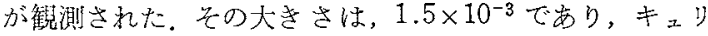
一温度直下 $(570 \mathrm{~K})$ での熱膨張係数は， $-40 \times 10^{-6} \mathrm{deg}^{-1}$ と いら大きな負の值を持つ。

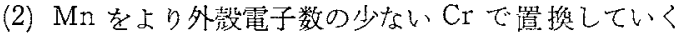
之，まず最初，キュリー滥度直下での格子の収緶が小さく なり，そ机ともない，俱の熱膨張係数も小さくなってい く(試料 2 ).

(3) 次いで，格子の収緶が観測されなくなりキェリー 温度以下の広い温度範囲での熱膨張係数が， $1 \times 10^{-6} \mathrm{deg}^{-1}$ 以下といら，非常に優れたインバー特性を持つようになる (試料 3,4 ).

（4）さらに置換舅が增大すると，キェリ一温度付近での 熱膨張は，逆にだんだんと大きくなるが，熱骴張係数は， 依然小さく、インバー特性を有することがわかる(試料 5 )。

(5) Mnをより外教電子数の多いFeで盖換していくと，

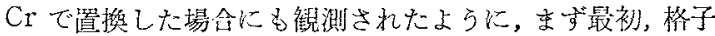
の取縮は小さくなり(試料 9 )，次いでキュリ一盓度近

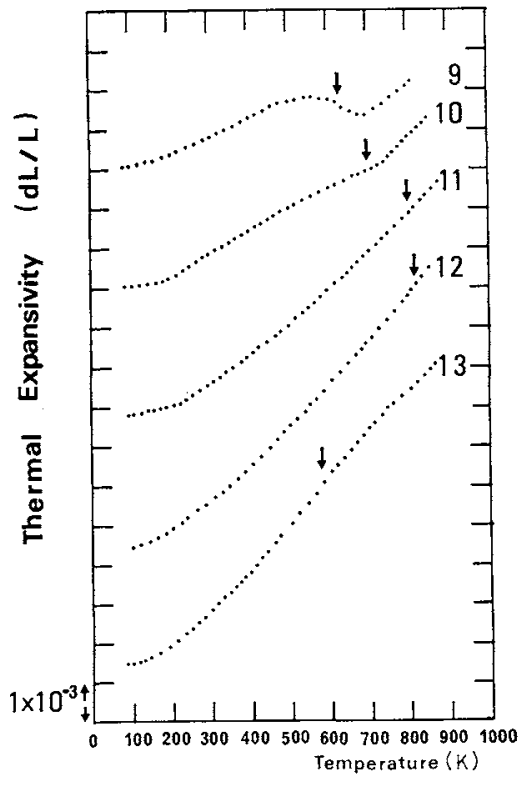

$9:\left(\mathrm{Mn}_{0.90} \mathrm{Fe}_{0.10}\right) \mathrm{B}, 10:\left(\mathrm{Mn}_{0.80} \mathrm{Fe}_{0.20}\right) \mathrm{B}, 11:$

$\left(\mathrm{Mn}_{0.60} \mathrm{Fe}_{0.40}\right) \mathrm{B}, 12:\left(\mathrm{Mn}_{0.40} \mathrm{Fe}_{0.60}\right) \mathrm{B}, 13: \mathrm{FeB}$

Fig.2 Temperature dependence of the thermal expansivity of $\left(\mathrm{Mn}_{1-x} \mathrm{Fe}_{x}\right) \mathrm{B}$. The arrows show the Curie temperatures(16). The numbers shown in the figure indicate the sample numbers. 
傍での熱膨辳係数が小さくなる(試粼 10)が, $\left(\mathrm{Mn}_{1-x} \mathrm{Cr}_{x}\right) \mathrm{B}$ 系で，観測されたよらな優れたインバ一特性は持たなかっ た.

（6）より置觔量が增大すると，磁気体積効果は小さくな

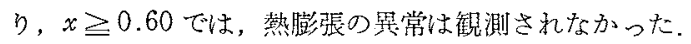

(7) キュリー温度以上での蓺膨張係数は，全ての試料比 ついて大体同じで方り，例えば，700 K 付近での熱膨張係 数は, $12 \times 10^{-6} \mathrm{deg}^{-1}$ 程度である。

以上の結果から，これらの系での置常な熱膨竖の等動 は，大きな正の体積磁歪の存在によると考允られる。ここ で測定て供した試料は，全て焼結体であり，X線回折強度 の測定の結果からも特別な結晶方位に配向していないこと が充分確かめられた。したがって熱膨器は等方的であり， 3軸方向の熱膨㖘の斗均であると考方られる。李た試料の 焼結は， $1150^{\circ} \mathrm{C}$ で行っており，こ机は，熱膨張の測定最

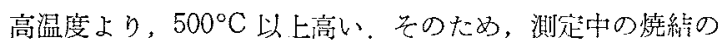
進行は無視でき，これた起西る格子の取維を考䈍する必 要はない。よって温度 $T$ での自登体榬磁歪 $\omega_{s}(T)$ は次式 によって求めることができる。

$$
\omega_{s}(T)=3\{(\Delta L / L) \text { T.F. }-(\Delta L / L) \text { T.P. }\}
$$

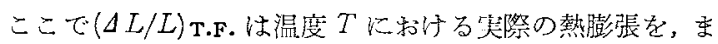

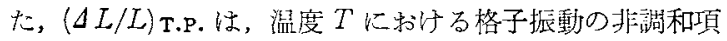

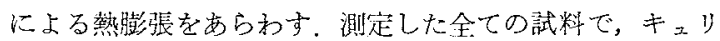
一温度以上での熱膨張係数が大体同じであること，および $\left(\mathrm{Mn}_{1-x} \mathrm{Cr}_{x}\right) \mathrm{B}$ で $x \geqq 0.50$ の なた $\left(\mathrm{Mn}_{1-x} \mathrm{Fe}_{x}\right) \mathrm{B}$ で, $x \geqq$ 0.60 の組成䇢囲のものは，熱膨㖘に異常を示さず，熱膨 援曲線は，よく類似していることに着目してこれらの试

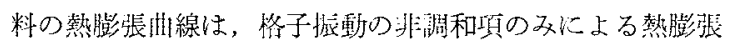

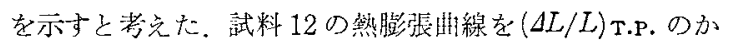

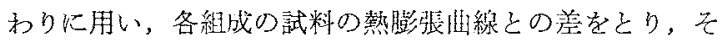
れを 3 倍して， $\omega_{s}(T)$ とした。上上のよらにして得た $\omega_{s}(T)$ の温度変化をFig.3汇示す。金ての $\omega_{s}(T)$ が低温で,

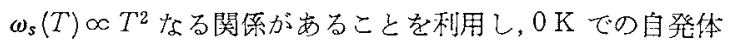
積磁歪 $\omega_{s}(0)$ を求めた。 $\omega_{s}(0)$ 心組成変化を Fig.4に示す. $\mathrm{MnB}$ での $\omega_{s}(0)$ は $1.6 \times 10^{-2}$ であり，この值は， $\gamma$ Fe-Ni やFe-Pt 等の他のインバー合金の $\omega_{s}(0)$ と同程度の大きさ を持っている， $\omega_{s}(0)$ は， $\mathrm{MnB}$ で最大值をとり， $\mathrm{Cr}, \mathrm{Fe} の$ 置與量增大以とるない，急激汇減少し， $\left(\mathrm{Mn}_{1-x} \mathrm{Cr}_{x}\right) \mathrm{B}$ 系 では $x=0.50$ で, $\left(\mathrm{Mn}_{1-z} \mathrm{Fe}_{x}\right) \mathrm{B}$ 采では, $x=0.60$ で $\omega_{s}(0)$ は0となる. PerkinsとBrown"(14)火上れば, FeBでの

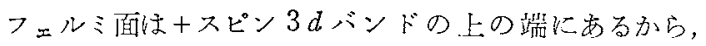
rigid band theory の立場比立てば，FeBよりも，金属 原子㐫たりの外篗電子数が少ない $\left(\mathrm{Mn}_{1-x} \mathrm{Fe}_{x}\right) \mathrm{B}$ 系では，

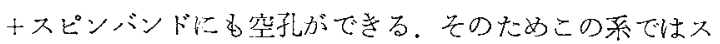
トーナー条件を満たさない強磁性であると考えられる、ス

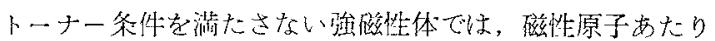
の電子数の変化により, 自癹酳気モーメントが絽成の变化 に詨して，不連続的にぜロになることが期待される(18)(19).

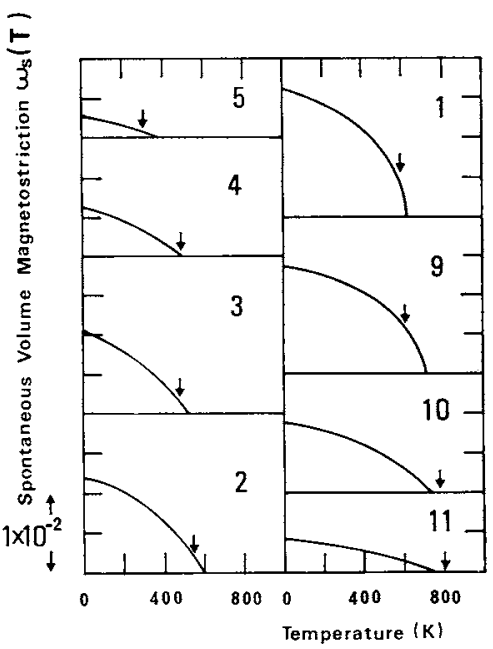

Fig.3 Temperature dependence of spontaneous volume magnetostricition of $\left(\mathrm{Mn}_{1-x} \mathrm{Cr}_{x}\right) \mathrm{B}$ and $\left(\mathrm{Mn}_{1-x} \mathrm{Fe}_{x}\right) \mathrm{B}$, evaluated from the observed thermal expansivity curve. The numbers shown in the figure indicate the sample numbers. The arrows show the Curie temperatures.

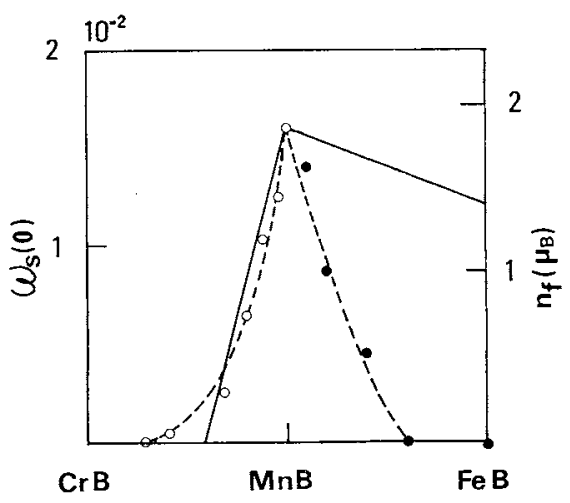

Fig.4 Spontaneous volume magnetostriction of $\left(\mathrm{Mn}_{1-x} \mathrm{Cr}_{x}\right) \mathrm{B}$ and $\left(\mathrm{Mn}_{1-x} \mathrm{Fe}_{x}\right) \mathrm{B}$ at $0 \mathrm{~K}, \omega_{s}(0)$, as a function of composition. Open and closed circles are the values for $\left(\mathrm{Mn}_{1-x}\right.$ $\mathrm{Cr})_{x} \mathrm{~B}$ and $\left(\mathrm{Mn}_{1-x} \mathrm{Fe}_{x}\right) \mathrm{B}$, respectively. The solid line shows the composition dependence of the spontaneous magnetic moment, $n_{f}$ at $0 \mathrm{~K}^{(16)}$.

この考えに従いFe-Ni 合 全の自発磁化の急激な娍少が䛠 明(20)(21)されている。Shiga ${ }^{(8)}$ ，Schlosser ${ }^{(9)}$ とよれば，自 発磁気モーメントが温度の上昇にともない減少することが 予想でき自癷磁気モーメントの存在により，膨誩した格子 が，磁気モ一メントの減少により，収維することによっ て，磁気体程效果が䛠明さ礼ている，MeB系での正の住 発体積磁专の出現と， $\left(\mathrm{Mn}_{1-x} \mathrm{Cr}_{x}\right) \mathrm{B}$ での磁気もーメント の急激な減少は，この系が Fe-Ni インバー合金と同様に， ストーナー条件を満たさない強磁性体であることを推論さ せる。 


\section{IV，結論}

(1) $\left(\mathrm{Mn}_{1-x} \mathrm{Cr}_{x}\right) B$ 系に乱いても，等溫优近でインバー 特性が得られた。

(2) 組成の局在的なゆらぎの称しない $\mathrm{MnBではキュ}$ リー埧度直下で大さな格子の収緶が観測された。

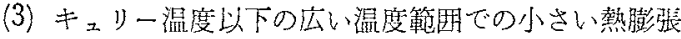

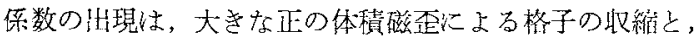

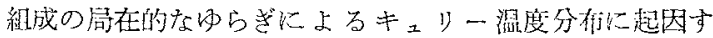
る。

(4) 磁気モーメントのキュリー温度以上での減少は，こ の系がナスピンにす空孔のあるストーナ一条件を㗲たさな い強磁性体であることによる。

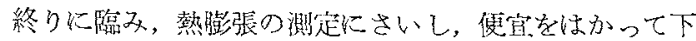

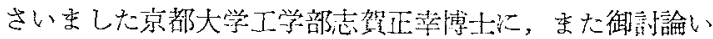
たださました京都大学工学部中村陽二教授に深く感謝致し 京す。

\section{文献}

(1) H.Saito and K.Fukamichi : IEEE Trans.Mag., $8(1972), 687$

（2）深渞和明，鉿木雄一，斎藤英夫：金属学会誌，37 (1973), 927.

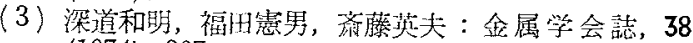
(1974), 327 .
(4) K.H.J.Buschow, A.R.Miedema and M.Brouha : J.Less-Common Metals, 38 (1974), 9.

(5) M.Shiga : Phys.Letters, 53 A (1975), 319.

(6) T. Shigematsu, S. Ohmori, N. Nakanishi and S.Kachi : J.Phys.Soc.Japan, 38(1975), 1213.

(7) T.Shigematsu : J.Phys. Soc. Japan, 39(1975), 915.

(8) M. Shiga : AIP Conference Proceedings, 18 (1974), 463 .

(9) W.F.Schlosser: AIP Conference Proceedings, $24(1974), 441$.

(10) R.Kissling : Acta Chem.Scand., 4(1950), 209.

(11) M.C.Cadeville and A.J.P.Meyer : C.R.Acad. Sci.(Frans), 25 (1962), 3391.

(12) N.Lundquist and H.P.Myers : Ark.Fys., 20 (1962), 463

(13) N.Lundquist,H.P.Myers and R. Westin : Phil. Mag., $7(1962), 1187$.

(14) R.S.Perkins and P.J.Brown : J.Phys. F, 4 (1974), 906.

(15) T.Shigematsu, T. Kanaizuka, K. Kosuge, M. Shiga, Y. Nakamura and S. Kachi : Phys. Letters, $53 \mathbf{A}(1975), 385$.

（16）重公利养，金茾潒唯人，可知祐次：未発表。

(17) D.Hohnke and E.Parthé : Acta Cryst., 20 (1966), 583.

(18) M.Shimizu : Proc.Phys.Soc., 84(1964), 397.

(19) M. Shimizu : Proc.Phys.Soc., 86(1965), 147.

(20) M.Shimizu and S.Hirooka: Phys.Letters, $27 \mathbf{A}$ (1968), 530 .

(21) T. Mizoguchi : J. Phys. Soc. Japan, 25 (1968), 904.

\section{微量添加元素を含む Al-Zn 合金の G.P.ゾーンと その伝導現象への寄与}

\section{平 岡 裕* 長 村光造** 村上陽太郎**}

Yutaka Hiraoka, Kozo Osamura and Yotaro Murakami : G.P.Zones in Al-Zn Alloys Containing a Small Amount of Additional Elements and Their Contribution to Transport Phenomena. In order to determine experimentally the scattering power of the G.P.zones in Al-Zn-Si, $\mathrm{Al}-\mathrm{Zn}-\mathrm{Ag}$ and $\mathrm{Al}-\mathrm{Zn}-\mathrm{Mg}$ alloys, in which the effect of a small amount of third elements $\mathrm{Si}, \mathrm{Ag}$ and $\mathrm{Mg}$ on the formation and growth of G.P.zones is known to be different from each other, the changes in electrical resistivity and $\mathrm{X}$-ray small-angle scattering during aging at $20^{\circ} \mathrm{C}$ have been measured. It is shown that the size dependence of the scattering power of a G.P.zone in each ternary alloy is explained in terms of the difference of the solute concentration in zones and the effect of the third elements in zones on the scattering power, especially for the A1- $\mathrm{Zn}-\mathrm{Ag}$ and $\mathrm{Al}-\mathrm{Zn}-\mathrm{Mg}$ alloys.

\section{(Received March 13, 1976)}

\section{1. 緒言}

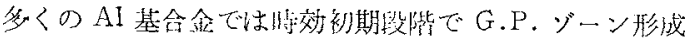

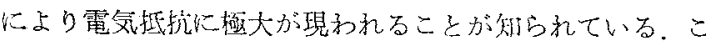

の現象が G.P.ゾーンの存在するはっきりした証扰である と見なされている。このような析出物の電気抵划への等与。 についてはMott(1) 以来多くの理諭的および来験的研究が なされてきた。我々はこれまてに球状 G.P.ゾーンが形成

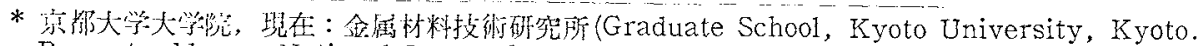

Present address: National Research Institute for Metals, Tokyo)

** 㷛都大学工学部治金学教室 (Department of Metallurgy, Faculty of Engineering, Kyoto University, Kyoto) 